DOI 10.37882/2223-2982.2020.06-2.30

\title{
«ДЕЛО СВЕРДЛОВСКОЙ ЛЕЧКОМИССИИ»: КОРРУПЦИОННЫЕ ПРАКТИКИ НА УРАЛЕ В ПЕРВОЙ ПОЛОВИНЕ 1930-Х ГОДОВ
}

\section{«THE CASE OF THE SVERDLOVSK MEDICAL COMMISSION»: CORRUPTION PRACTICES IN THE URALS IN THE FIRST HALF OF THE 1930S}

\section{A. Sushkov}

Summary: The article considers the daily life and administrative practices of party and economic officials of the city of Sverdlovsk, Ural (Sverdlovsk) region, in the first half of the 1930s. On the basis of documents of party control bodies from the Center of documentation of public organizations of the Sverdlovsk Region it analyzes the facts of illegal spending of financial and material resources for personal purposes. According to documents, the source of luxurious life of the local party nomenclature, in addition to budgetary funds, was financial resources of enterprises, organizations and institutions. The author concluded that corruption activity of economic and party leaders adversely affected the implementation of industrialization plans. Heads of government agencies who had been convicted of corruption suffered only symbolic punishment.

Keywords: party and state system of the power, economic crimes, corruption, industrialization, the Party Control Commission of the Central Committee of CPSU(b), Ural, Sverdlovsk.
Сушков Андрей Валерьевич

К.и.н., С.н.С., Институт истории и археологии Уральского отделения Российской академии наук (г. Екатеринбург) suschkow@mail.ru

Аннотация: В статье рассмотрены повседневная жизнь и управленческие практики партийных и хозяйственных руководителей г. Свердловска Уральской (Свердловской) области в первой половине 1930-х годов. На основе документов органов партийного контроля, находящихся на хранении в Центре документации общественных организаций Свердловской области, проанализированы факты незаконного расходования финансовых и материальных ресурсов в личных целях. Как свидетельствуют документы, источником роскошной жизни местной партноменклатуры, помимо бюджетных средств, являлись финансовые ресурсы предприятий, организаций и учреждений. Автор пришёл к выводу, что коррупционные действия хозяйственных и партийных руководителей негативно сказывались на осуществлении планов индустриализации. Руководители властных структур, уличённые в коррупции, понесли лишь символическое наказание.

Ключевые слова: партийно-государственная система власти, хозяйственные преступления, коррупция, индустриализация, Комиссия партийного контроля при ЦК ВКП(б), Урал, Свердловск.
$\mathrm{T}$ ема коррупции во властных структурах и хозяйственных организациях на Урале в 1930-е гг. всё чаще привлекает к себе внимание историков. Некоторые «дела», фигурантами которых стали первые лица местных властных структур, уже попадали в поле зрения специалистов [1, с. 25-26; 2; 3; 4; 5, с. 471-512; 6; 7, с. 67$68 ; 8 ; 9 ; 10]$. Однако «дело Свердловской лечкомиссии» ещё не становилось предметом специального научного исследования.

Как свидетельствуют архивные документы, в начале 1930-х годов руководители Уральской области были озабочены не только строительством гигантов советской индустрии, но и обустройством загородных зон отдыха для партноменклатуры. В пригороде Свердловска, вблизи крупных водоёмов появились элитные дома отдыха, доступ к которым имели лишь высокопоставленные руководящие работники и члены их семей. Но первых лиц области нельзя было заметить среди отдыхающих: они предпочитали проводить свой досуг подальше от посторонних глаз. На живописном острове Репный на Шитовском озере для первого секретаря обкома И.Д. Кабакова и двух его ближайших соратников были возведены роскошные загородные резиденции. На острове были про- ведены работы по преобразованию дикой природы в садово-парковую территорию: вокруг дач стояли круглые мраморные столы, вдоль липовых аллей располагались изящные гипсовые скульптуры, были установлены фонтаны, скамейки для отдыха и беседки. К озеру специально была проложена прямая многокилометровая дорога, а на берегу была сооружена пристань, с которой облечённых властью пассажиров на больших лодках доставляли на остров [8, с. 92-94].

Свердловское горкомовское начальство старалось не отставать от областных «вождей». Несмотря на то, что в распоряжении «столичного» горкома уже был дом отдыха на озере Шарташ, у первого секретаря горкома Ф.И. Карклина, второго секретаря Ф.И. Стриганова, а также инструктора горкома и по совместительству председателя лечебной комиссии Н.П. Масленникова возникла идея построить ещё один дом отдыха в живописном месте на берегу Чусовского озера, что южнее Свердловска. «Это было в кабинете Карклина, - рассказывал потом партийным следователям Николай Павлович Масленников. - Говорили о том, что актив живёт в трудных условиях, что-то надо предпринять, чтобы этот актив устроить, и решили построить дом отдыха пар- 
тийного актива». Руководить всеми работами по строительству, оборудованию и благоустройству территории поручили председателю лечкомиссии Масленникову. Он отправился на озеро, где выбрал подходящее место для отдыха «бедствующего» актива. Одновременно для обслуживания дома отдыха продовольствием решили создать сельхозкомбинат. Кроме того, постановлением президиума Свердловского горсовета от 20 апреля 1934 года за домом отдыха закрепили не только Чусовское озеро, но и ряд других, расположенных вокруг Свердловска: Чёрное, Глухое, Половинное и Шувакиш, где для обслуживания начальства предполагалось создать рыбные хозяйства $[11$, л. 36, 55, 64].

Пользуясь случаем, Карклин и Масленников организовали себе отдельные дачи, находившиеся на противоположном берегу озера. Как и в случае с дачей Кабакова, чтобы добраться до них, нужно было переправляться по озеру, автомобильная дорога отсутствовала. Проектированием дач занимался специально приглашённый инженер. Дачи включали в себя шесть комнат - пять внизу и одна наверху. Второй этаж зданий был построен в виде мансарды с верандой. Обе дачи были обиты материей, для них были приобретены дорогостоящие мебель, ковры и ковровые дорожки, посуда. Разумеется, на дачах была организована охрана, имелась прислуга. Для подведения к дачам электричества потребовался специальный морской кабель длиной 3 километра, предоставить который взялась одна из ленинградских контор. Взамен ленинградцы попросили вагон металла. Горкомовским чиновниками ничего не стоило договориться с ВерхИсетским металлургическим заводом о получении требуемого [11, л. 47, 82, 86, 245].

С целью приобретения обстановки для дач Карклина и Масленникова, а также для Чусовского дома отдыха в Ленинград и Москву были командированы заместитель председателя горлечкомиссии А.А. Гончаров и начальник строительства Дома культуры героев Гражданской войны и труда С.Б. Кроль - беспартийный и дважды судимый бывший торговец, имевший обширные связи в различных государственных структурах и торговых организациях. О последнем говорили: «крупный специалист, коммерсант, везде всё достанет». Перед командированными была поставлена задача приобрести эксклюзивную мебель и посуду. Закупки производились в комиссионных и антикварных магазинах. В этих магазинах были куплены пять столовых сервизов стоимостью от двух до трёх тысяч рублей каждый, вазы, винные сервизы, бокалы, графины и даже пивная кружка, исполняющая во время пользования ею музыкальные номера $[11$, л. 73, 245-246].

Деньги текли рекой. Стоимость одного только оборудования дач и дома отдыха проверяющие определили в 258 тысяч рублей. Кроме того, почти в 20 тысяч обо- шлись расходы на поездки Кроля и Гончарова, которые не удержались от соблазна присвоить себе некоторую часть из денежного потока, проходившего через их руки. А поток этот был немалым: только Самуил Борисович Кроль имел на собственном счёте более 150 тысяч рублей. Содержание дома отдыха и дач тоже выливалось в «круглую сумму».

Чусовской дом отдыха располагался на расстоянии 27 километров от Свердловска. Большую часть пути - 20 километров - приходилось преодолевать по грунтовой разбитой дороге. Некоторые начальники ежедневно отправлялись с дачи в город и вечером возвращались обратно, гоняя машины в общей сложности на расстояние более 100 километров. В распоряжении отдыхающих были пиво, дорогие вина и изысканные кушанья. Большой банкет на 100 человек закатили в день открытия дома отдыха. Водка, вино, портвейны лились рекой, не обошлось без драк (заместитель председателя горсовета Ф.А. Березин увидел поцарапанное лицо своей жены, упавшей в пьяном виде без чьей-либо помощи, почемуто счёл виновным в произошедшем зампреда Горпотребсоюза Пищика и побил как жену, так и ни в чём не повинного Пищика, а заодно пытавшуюся предотвратить мордобой кастеляншу).

Удалённость дач Карклина и Масленникова вызывала дополнительные расходы, связанные с доставкой с Чусовского дома отдыха приготовленных обедов и организацией на этих дачах банкетов для избранных [11, л. $7-8,85-86,95,233,245]$.

Финансирование строительства загородных резиденций для партноменклатуры, а также их содержание осуществлялось из средств лечебной комиссии, созданной при Свердловском горкоме ВКП(б). Основной поток средств Свердловской лечкомиссии был направлен на строительство, приобретение мебели и прочего имущества для дач горкомовского начальства и Чусовского дома отдыха. Но только этим её деятельность по обеспечению материально-бытового обслуживания партноменклатуры не ограничивалась. Часть средств была выплачена партийным, советским и хозяйственным руководителям в виде денежных пособий. Самые крупные пособия получили (наряду с горкомовским руководством) те хозяйственники, чьи организации не скупились на улучшение материально-бытовых условий для партноменклатуры. Так, начальник горстройтреста Кузин получил от горлечкомиссии 2400 рублей, от областной комиссии - 200 рублей и две путёвки на элитные южные курорты. Подобным же набором благ был удостоен директор Свердпищеторга Саплин. Всего на эти цели лишь за неполный 1934 год было потрачено без малого 115 тысяч рублей [11, л. 244].

Имея доступ к деньгам, главное горкомовское на- 
чальство использовало их для улучшения своего благосостояния - покупки дорогостоящих вещей не самой первой необходимости. Первому секретарю Свердловского горкома ВКП(б) Фрицу Ивановичу Карклину в Москве купили часы за 400 рублей. Инструктор горкома и председатель лечкомиссии Масленников обзавёлся импортным патефоном и пластинками к нему, кожаным пальто и швейцарскими ручными часами фирмы «Мозер». Заместитель Масленникова - Гончаров стал владельцем швейцарских часов фирмы «Павел Буре». Начальник снабжения лечкомиссии Питерский получил в собственность патефон и кожаное пальто. Заведующему Чусовским домом отдыха Санникову достались дорогостоящие ручные часы. Если не все вышеперечисленные, то подавляющее большинство покупок были совершены «представителем» лечкомиссии Кролем в магазинах Торгсина, для чего он скупал торгсиновские боны по спекулятивным ценам у старателей [11, л. 148-151, 206-208].

Следует отметить, что партийный бюджет не позволял осуществлять такие огромные расходы на материально-бытовое обслуживание партноменклатуры. Судя по документам, основной статьёй дохода для Свердловской лечкомиссии являлись денежные и материальные ресурсы местных хозяйственных организаций и различных государственных учреждений.

Руководители Свердловска прекрасно осознавали, что строительство дома отдыха на Чусовском озере не обеспечено ни финансовыми ресурсами, ни строительными материалами. Собрать необходимые средства они планировали с подведомственных городских хозяйственных и советских организаций, коих насчитали 84. По предварительным прикидкам, предполагалось получить с них в общей сложности более полумиллиона рублей (566 800 рублей). Хозяйственников вызывали в горком к Масленникову или его заместителю Гончарову и уговаривали их перечислить нужные суммы в горлечкомиссию. Партийное начальство заранее заготовило бланки поручений в коммунальный банк, где требовалось лишь поставить денежную сумму и расписаться. Хозяйственников приглашали также на специально устроенные вечера со спиртным, где в произносимых тостах призывали помочь «хорошему делу». Взамен обещали места в домах отдыха, путёвки на южные курорты и денежные пособия [11, л. 62, 197-198, 251-252].

И деньги пошли. Значительные средства перечислили Уралбродтрест - 27 тысяч рублей, Свердпромторг 13 тысяч рублей, Свердлес - 10 тысяч, Свердпищеторг - 5 тысяч рублей. Но гораздо более крупные суммы перечислили организации союзного значения, такие как Уралхиммашстрой в лице директора Тарыгина - почти 310 тысяч рублей, Уралэнерго (помощник управляющего Львов) - 170 тысяч, завод «Металлист» (директор Миков) - почти 150 тысяч, Востокоруда (заместитель управляю- щего Иванов) - 37 тысяч [11, л. 250-251].

Руководители Уралхиммашстроя, Востокоруды и завода «Металлист» изымали денежные суммы из средств, предназначенных для жилищного строительства [11, л. 57, 209]. Руководители горкома партии прекрасно знали, какое происхождение имеют перечисленные на счета лечкомиссии средства. Не только знали, но и «подсказывали» хозяйственникам, где можно взять деньги. «Я помню, я попросил к себе замдиректора комбанка товарища Свердлова и попросил его указать мне источники в пределах законности, за счёт которых мы могли бы вести строительство, - заявлял позже Масленников. - Он мне указал на единственный источник - это путём договорённости с хозяйственными организациями, которые имеют средства на жилищно-коммунальное строительство и их не используют. Таким образом, передача от них неиспользованных, неосваеваемых кредитов на жилищно-коммунальное строительство, на наше строительство. Тут же он мне указал технику этого дела. Позднее, когда Свердлов был отозван, мы эту работу проводили в части организации финансирования через посредство современного директора комбанка Казанцева. Он нам сообщал, в каких организациях имеются неиспользованные кредиты, мы разговаривали с этими организациями и просили, чтобы они эти кредиты нам передавали. Таким путём решались вопросы финансирования» [11, л. 199].

Начальник Уралхиммашстроя Г.Е. Тарыгин в беседе с уполномоченным Комиссии партконтроля при ЦК ВКП(б) Л.А. Папардэ подтвердил показания Н.П. Масленникова: «Вызвал к себе Масленников. Говорит, что мы строим лечебницу, у нас денег нет, что у тебя деньги на жилстроительство не использованы. Я согласился дать и дал из средств на жилстроительство».

В ходе диалога между Папардэ и Тарыгиным, кроме всего прочего, прояснилось отношение хозяйственника к жилищным проблемам рабочих во вверенной ему организации:

- Папардэ: «Как проводите [перечисление средств] по своей отчётности?»

- Тарыгин: «У нас не проходит по отчётности, это остаются неосвоенные деньги, остаются они в банке у государства как неосвоенные. В нашем отчёте никак не проходят. Всё равно: или бы эти деньги пошли сюда, или бы остались в кармане государства».

- Папардэ: «Почему не освоили эти деньги на жилстроительство? У вас ведь жилбытовые условия безобразные?»

- Тарыгин: «Мы вообще плохо строим. Жилищные условия плохие, но не строим и сейчас».

На вопрос: «Чем руководствовался, давая деньги? 
Что это - горком?» Тарыгин отвечал: «Я руководствовался тем, что он строит лечебницу. Знаю, что денег нет, что деньги у меня на площадке не будут освоены. Что эти деньги пойдут на лечебную организацию, которой будут пользоваться люди. Этим и руководствовался» [11, л. 76-77].

Людьми, таким образом, Тарыгин считал партийную номенклатуру и хозяйственное начальство - ту касту, к которой принадлежал сам. Рабочих на строительстве Тарыгин, судя по его словам, за людей не держал.

Всего, по подсчётам партконтроля, только с городских хозяйственных организаций и различных учреждений удалось собрать 263 тысячи рублей, не считая финансовых средств, перечисленных Уралхиммашстроем, Уралэнерго, заводом «Металлист» и Востокорудой [11, л. 250-251].

Некоторые организации расплачивались имевшимися материальными ресурсами. Так, облснаб, горснаб, горнарпит поставляли продукты питания. Завод «Металлист» передал в распоряжение горлечкомиссии алебастр, железо, стекло, бензин и различное оборудование общей стоимостью почти 13 тысяч рублей. Силами завода были проведены большие работы по строительству Чусовского дома отдыха на сумму более 23 тысяч рублей [11, л. 217, 250].

Весьма любопытные манипуляции были проведены с лесным участком, где началось строительство Чусовского дома отдыха. Свердлестрест передал лечкомиссии Широкореченский лесной участок вместе с расположенными там строениями. Директор Свердловского леспромхоза Е.С. Санников, в непосредственном ведении которого находился этот участок, за услужливость получил место начальника строительства и заведующего домом отдыха. Позже Масленников договорился с директором Свердпищеторга Н.С. Саплиным о продаже торгу находившегося на территории участка круглого леса, якобы годного для строительства. Свердпищеторг за эти лесоматериалы перечислил весьма немалые деньги 208930 рублей. Фактически же никакого пригодного для строительства круглого леса не было, передавать было нечего, что прекрасно было известно как Масленникову, так и директору Свердпищеторга Саплину. «Откровенно говоря, что просто-напросто нужны были деньги, Саплин дал деньги под видом того, что вы напилите лес, а я вам дам деньги», - пояснял при опросе в партконтроле заведующий снабжением лечкомиссии В.Ф. Питерский. Фиктивность договора со Свердпищеторгом позже признал и Масленников [11, л. 53, 55, 68, 207, 209, 214, 250].

Директор Свердпищеторга Саплин не остался без материальной помощи со стороны властных структур. За услуги он получил наличными от городской лечко- миссии 2400 рублей, от областной лечкомиссии - 450 рублей и путёвку на элитный курорт. Саплину выплатили даже больше, нежели второму секретарю горкома Стриганову, получившему на руки «лишь» 2200 рублей [11, л. 244].

Если с одними организациями городские власти вынуждены были считаться, стремились материально заинтересовать их руководство, то у других забирали имущество без лишних разговоров и каких-либо компенсаций. В связи с этим весьма примечательна судьба нескольких зданий, которым было суждено оказаться в сфере интересов городского начальства. Дело в том, что не все строения в районе Чусовского озера принадлежали леспромхозу и перешли в ведение горсовета, лечкомиссии и дома отдыха. Ещё в 1921 году екатеринбургская детская комиссия приобрела на Чусовском озере дачи и передала их в распоряжение детского приёмника для размещения там, на этих дачах, в летнее время беспризорных детей. Дети не только отдыхали, но и занимались в лесу заготовкой грибов и ягод, работали на огороде. Результаты их труда позволяли разнообразить и существенно пополнить меню в столовых детского приёмника. Так продолжалось до тех пор, пока лечкомиссия не присмотрела Чусовское озеро для строительства собственного дома отдыха и дач. В 1933 году председатель лечкомиссии Масленников потребовал от детприёмника освободить дачи, заведующий гороно Аносов со своей стороны поддержал эти указания. В бывших дачах детприёмника разместили рабочих, занятых на строительстве дома отдыха. Взамен гороно предоставило приёмнику на летний период здания школ в двух деревнях, где «на радость» местным жителям дети принялись «осваивать» чужие огороды. Обращения детской комиссии и детприёмника в областные и центральные инстанции с просьбами вернуть бывшие дачи на Чусовском озере оставались без ответа [11, л. 34].

Ради получения финансовых средств и нужных материальных ресурсов Свердловская лечкомиссия, так же как и областной хозупр, занималась спекуляциями добытых разными путями продуктов и дефицитных стройматериалов. Вдвое дороже перепродавали цемент и алебастр. Сотнями килограммов продавался ржаной хлеб и свежая рыба мебельному комбинату «Прогресс», свинина - ресторану «Большой Урал», бензин - горпотребсоюзу. Проводились и различные финансовые махинации [11, л. 249].

Многочисленные коррупционные преступления свердловского начальства были выявлены и задокументированы аппаратом уполномоченного Комиссии партийного контроля при ЦК ВКП(б) по Свердловской области. Уполномоченный КПК Л.А. Папардэ вместе со своими сотрудниками прилагал все усилия, чтобы причастные к незаконному расходованию средств были 
привлечены к ответственности.

Решением уполномоченного и партколлегии свердловского партконтроля от 26 августа 1934 года председатель Свердловской городской лечкомиссии, член бюро горкома ВКП(б) Н.П. Масленников, начальник снабжения комиссии Питерский и директор Чусовского дома отдыха Санников были исключены из партии с привлечением к уголовной ответственности «за разбазаривание государственных средств и другие злоупотребления». «За участие в преступной деятельности горлечкомиссии и связь с жуликом и проходимцем Кролем» из партии был исключён заместитель Масленникова - Гончаров. Партконтроль постановил исключить из ВКП(б) и снять с работы директора завода «Металлист» Микова, «как злостного нарушителя дисциплины партии и государства, распоряжающегося государственными средствами и материальными фондами как своими личными». Директора Свердпищеторга Саплина «за заключение незаконных сделок с горлечкомиссией и разбазаривание государственных средств» было решено привлечь к уголовной ответственности. Начальнику Уралхиммашстроя Тарыгину «за разбазаривание государственных средств» объявили строгий выговор. Выговоры получили бывший второй секретарь Свердловского горкома Стриганов, заместитель председателя горсовета Березин и другие городские начальники [11, л. 226-228].

Если вынести взыскание и даже отнять партбилет партконтроль ещё мог, то вот добиться реального уголовного наказания для бывших начальников оказалось гораздо сложнее. Состоявшийся в сентябре 1934 года в Свердловске областной суд признал Масленникова, Гончарова и Питерского виновными и приговорил каждого к лишению свободы сроком на три года, но для последних двух это выразилось в оставлении под подпиской о невыезде, а Масленников пребывал под поручительством. Саплин и управляющий областным коммунальным банком Казанцев были судом оправданы (Саплину суд объявил лишь предостережение за «недостаточную осторожность в действиях при заключении договора с работниками горлечкомиссии») [11, л. 203-212].

Осуждённые так и не были подвергнуты лишению свободы. Сделать такой вывод можно хотя бы на том основании, что после суда Н.П. Масленников, «отбывавший наказание» на должности заместителя начальника механического цеха Златоустовского металлургического завода, принялся настаивать в цековской КПК на восстановлении в партии. Положительную характеристику ему для этих целей выдал бывший непосредственный начальник - первый секретарь Свердловского горкома ВКП(б) Ф.И. Карклин. Постигшая в первый раз неудача не заставила Масленникова опустить руки, и он вновь и вновь требовал от КПК восстановления в партии [11, л. 236-241]. Настойчивость проворовавшегося чиновника вполне понятна, ведь с лишением партбилета закрывалась дорога к высоким номенклатурным постам, раз и навсегда нужно было забыть о номенклатурных привилегиях. Не случайно директор Свердпищеторга Саплин в беседе с сотрудником партконтроля Носовым согласился с обвинениями в нарушении «железной дисциплины партии и государства» и высказал лишь одну просьбу: «Я единственно прошу сохранить в партии. Пошлите меня хоть землю копать на 10 лет, но оставьте в партии, я ещё буду полезен для партии. Это моя единственная просьба» [11, л. 100-100 об.].

Первый секретарь Свердловского горкома ВКП(б) Ф.И. Карклин тоже отделался лишь партийным взысканием. Решением бюро Свердловского обкома ВКП(б) от 2 сентября 1934 года, где разбиралось «дело Свердловской лечкомиссии», ему был вынесен строгий выговор «за допущенную доверчивость и непринятие своевременных мер к проверке и очищению аппарата горкома и лечкомиссии от буржуазных перерожденцев Масленникова, Гончарова и др.» [12, л. 252].

Пока трудно с точностью определить масштабы материального ущерба, нанесённого коррупционными действиями свердловской партноменклатуры государству. Тем не менее, можно утверждать, что подобные действия в значительной степени негативно сказывались на проведении в жизнь планов индустриализации. Как показало «дело Свердловской лечкомиссии», незаконные действия фиксировались органами партийного контроля, и затем рассматривались в судебных инстанциях. Однако под суд попадали не «заказчики» - первые лица городской власти, а главным образом лишь непосредственные исполнители, да и тем выносились несопоставимо мягкие либо даже оправдательные приговоры. Действующие законодательные меры реагирования на коррупционные преступления оказались совершенно неэффективными по отношению к коррупции в свердловских властных структурах.

\section{ЛИТЕРАТУРА}

1. ВКкючён в операцию». Массовый террор в Прикамье в 1937-1938 гг. / отв. ред. 0.Л. Лейбович. 2-е изд., перераб. М.: РОССПЭН, 2009.318 с.

2. Воробьёв С.В. «Знаете, не поладил немного с Виссарионычем»: из истории политического самозванства на Урале в 1930-е гг. // Вестник Оренбургского государственного педагогического университета. Электронный научный журнал. 2015. № 4 (16). С. 91-106. 
3. Воробьёв С.В. «Я размахнулся... и ударил Молотова по щеке»: политическое самозванство на Урале в первой половине 1930-х гг. // Региональная история, локальная история, историческое краеведение в предметных полях современного исторического знания: сборник статей. Ижевск: Издательство Удмуртского университета, 2012. С. 508-517.

4. Воробьёв С.В. Парадоксы сталинской индустриализации на Урале: немецкие рабочие против советской бесхозяйственности и злоупотреблений // Документ. Архив. История. Современность: материалы IV Международной научно-практической конференции. Екатеринбург: Издательство Уральского университета, 2012. С. 320-325.

5. Границы и маркеры социальной стратификации в России XVII-XX вв.: векторы исследования / ред. Д.А. Редин. СПб.: Алетейя, 2018. 722 с.

6. Колдушко А.А. «Я нигде так бедственно не жил, как в Перми, и не буду жить!»: быт и нравы пермской номенклатуры середины 1930-х годов // Повседневность номенклатуры: сборник статей / под ред. В.П. Мохова, Н.А. Фролова. Пермь: Издательство Пермского национального исследовательского политехнического университета, 2013. С. 76-88.

7. Колдушко А.А. Кадровая революция в партийной номенклатуре на Урале в 1936-1938 гг.: дисс. ... канд. ист. наук. Пермь, 2006. 222 с.

8. Сушков А.В. «Дело Свердловского облисполкома». Привилегированная жизнь «уральских вождей» в первой половине 1930-х годов // Свободная мысль. 2019. № 3. С. 91-106.

9. Сушков А.В., Бедель А.Э., Пьянков С.А. «Так это по советским законам, а мы же в Тагиле!»: коррупционные практики на Среднем Урале в 1930-е гг. // Genesis: исторические исследования. 2019. № 11. С. 134-147.

10. Сушков А.В., Бедель А.Э., Пьянков С.А. Индустрия роскошной жизни: к вопросу о коррупционных взаимоотношениях руководителей уральских партийно-государственных структур и хозяйственных организаций в 1930-е годы // Genesis: исторические исследования. 2019. № 8. С. 69-88.

11. Центр документации общественных организаций Свердловской области (ЦДООСО). Ф. 236. 0п. 1. Д. 32.

12. ЦДООСО. Ф. 236. Оп. 1. Д. 28а.

( Сушков Андрей Валерьевич (suschkow@mail.ru).

Журнал «Современная наука: актуальные проблемы теории и практики»

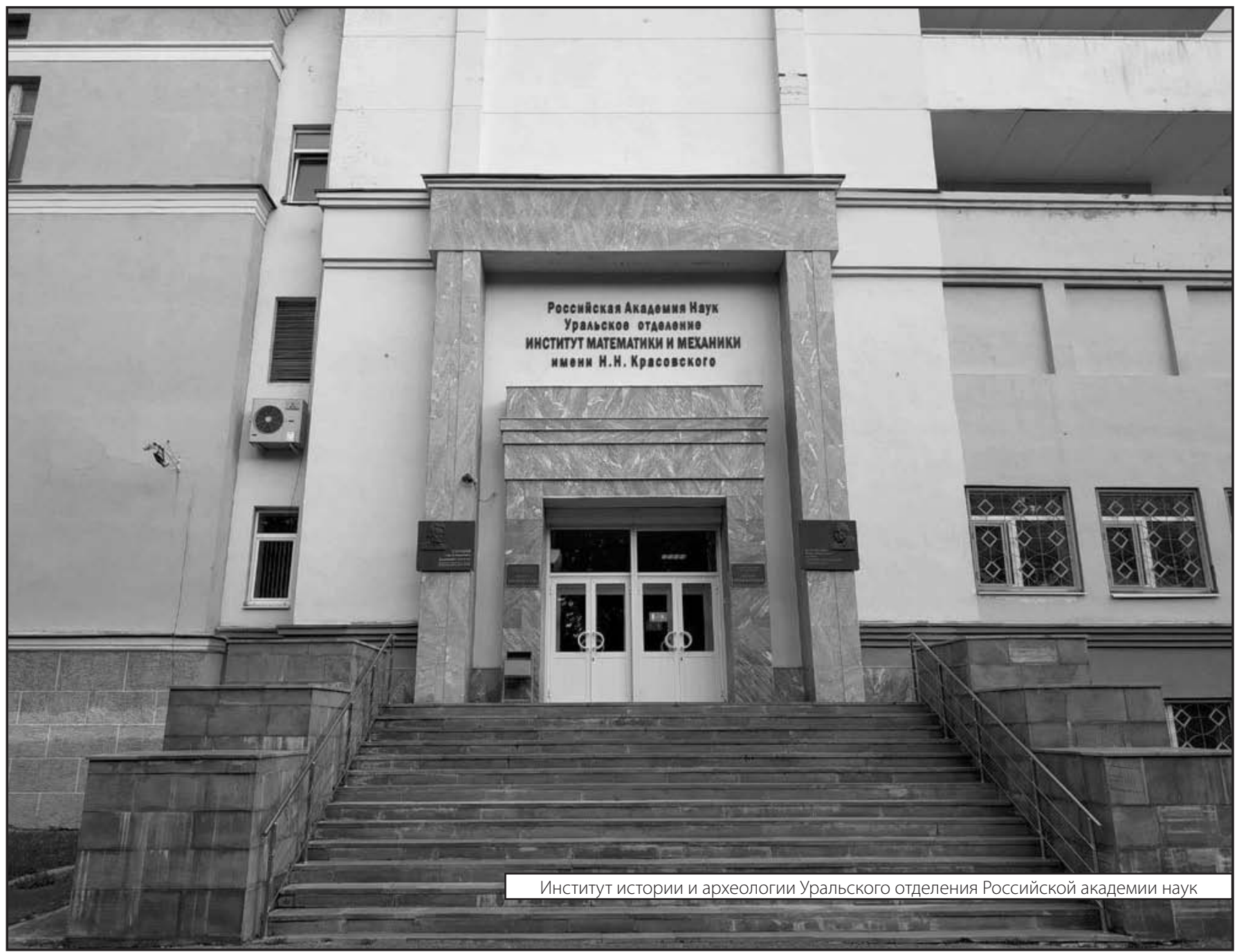

